\title{
Usefulness and Radiological Evaluation of Accuracy of the Innovative "Smart" Hand Technique for Pedicle Screw Placement: An Anatomical Study
}

\author{
Ayhan COMERT ${ }^{1}$, Ihsan DOGAN ${ }^{2}$, Y. Sukru CAGLAR ${ }^{2}$ \\ ${ }^{1}$ Ankara University, School of Medicine, Department of Anatomy, Ankara, Turkey \\ ${ }^{2}$ Ankara University, School of Medicine, Department of Neurosurgery, Ankara, Turkey
}

\section{ABSTRACT}

AIM: To use a smartphone application (app) during pedicle screw placement navigation and examine the accuracy of this application on an anatomical dry vertebrae model.

MATERIAL and METHODS: Seventy-six dry vertebrae were used for this study, and pedicle entry points and projections of pedicle screw trajectory lines in the lateral and superior aspects of the vertebral body were identified and drawn for each vertebra bilaterally. In each position, all angulations were measured directly before the procedure manually. One hundred and fifty two pedicle screws were inserted as a simulation of screw placement with the guidance of the angle-meter smart app. Accuracy of the method was tested according to the occurrence of bone penetration while the angular deviation of the inserted screws was evaluated in computed tomography images.

RESULTS: The mean deviation for 76 pedicle screws on the right side was $2.30^{\circ} \pm 1.78^{\circ}$ in the horizontal plane and $2.17^{\circ} \pm 1.57^{\circ}$ in the sagittal plane; and on the left side, $3.01^{\circ} \pm 1.83^{\circ}$ in the horizontal plane and $2.38^{\circ} \pm 1.68^{\circ}$ in the sagittal plane. No bone penetration occurred during 152 pedicle screw placements. According to the t-test results, there were significant differences between the two groups in the craniocaudal direction of the right side pedicle screws and in the craniocaudal direction of left sided pedicle screws.

CONCLUSION: The free smartphone app presented here as an angle-meter is a safe digital device for spinal instrumentation procedures. As a prototype of future pedicle screw fixation systems, it should be improved in terms of its feasibility and compatibility with screw probes. This may lead to a useful mobile digital angle-meter for spinal procedures.

KEYWORDS: Mobile health, Pedicle screw, Smartphone, Spine

\section{INTRODUCTION}

$\mathrm{S}$ afe and precise pedicle screw placement with proper technique emerges as the main challenge of spinal instrumentation. Although there are various techniques described and high-technology surgical devices and products invented, the aim of finding a more practical and accurate solution in terms of applicability and cost-effectiveness still maintains its popularity and actuality for spinal surgeons and the spine industry $(5,6,13,15,16,18)$.
The neuronavigation-guided spinal instrumentation procedures seem to be the safest option recently. Yet, due to their not showing real-time images, they cannot be considered exactly as an effective method. Although the accuracy of pedicle screw insertion is increased with the combined usage of these systems with intraoperative computed tomography (CT) showing the current real-time spine anatomy of patient, this may not be feasible in every spine center due to the large operation room necessity, high cost and long duration. 
There are various techniques based on anatomical landmarks defined in the lack of any imaging system. Furthermore, even if there are anatomical studies examining the spine anatomy on cadavers or radiological images for generating a safe pedicle insertion technique, application of these techniques and data to the deformed spine may lead to a mismatch and result in failure in case of lack of patho-anatomic measurements.

The present time is the "smart" century. Although a screw finding its way all by itself has not been developed yet, handheld devices attached to the screw holders guiding the surgeon for screw insertion are present in neurosurgical practice. Living in the so called "science age" takes us to a world penetrated with computer-based mobile devices like mobile phones, tablet computers etc. These devices themselves are considered to improve in the name of intelligence and smartness day by day. Additionally, current improvements have brought the "mHealth" terminology into usage (4). In the medical field, mobile applications (apps) seem to invade our daily practice during all the processes of education, diagnosis and treatment.

In this anatomical study, we described the concurrent use of a smartphone and digital angle-meter application in dry vertebrae and endeavored to smoothen the way of applying these hand-held computers in neurosurgical practice. Using a smartphone application for screw placement navigation was tested on an anatomical dry vertebrae model and the accuracy of this application was evaluated.

\section{MATERIAL and METHODS}

Using an anatomical dry vertebrae model, simulation of screw insertion with the aid of an angle-meter smart app was performed. Seventy-six dry vertebrae were evaluated in the Department of Anatomy, School of Medicine, Ankara University (Ankara, Turkey) (Figure 1A). Each vertebra was fixed by vice (Figure 1B). Before the procedure in each vertebra and after measurements and calculations, the midlines over the superior, inferior, posterior aspects of the vertebral body and pedicle screw entry point (PSEP) were identified and drawn specific to that vertebra considering the anatomical configuration of pedicle and vertebral body. Taking into consideration the PSEP as a starting point of the screw's trajectory, projections of the ideal pedicle screw trajectory according to the desired final position of each screw on the sagittal and horizontal planes over the lateral and superior aspects of the vertebral body were identified, drawn bilaterally and named as the superior projection of the pedicle screw trajectory line (SPSTL) and
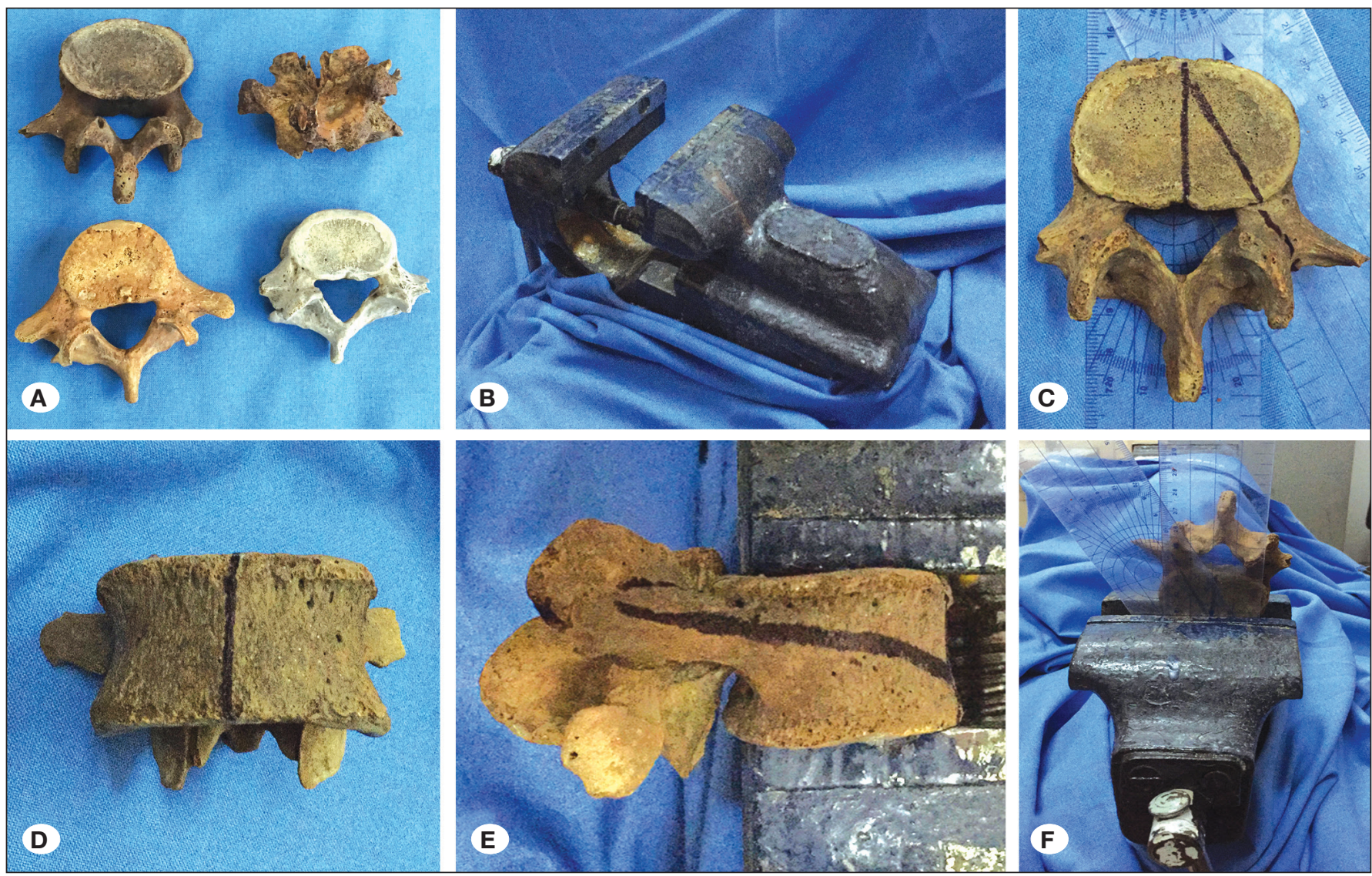

Figure 1: A) Various types of vertebrae samples in our study. B) Vice. C) Lines showing the midline and superior projection of the pedicle screw trajectory line (SPSTL) over the endplate of the vertebra. D) Line showing the midline over the anterior aspect of the vertebra. E) Lateral projection of the pedicle screw trajectory line (LPSTL) over the lateral aspect of the vertebra. F) Manual measurement of angulations on a vertebra fixed by vice. 
lateral projection of the pedicle screw trajectory line (LPSTL) respectively in each vertebra (Figure 1C-F). Seventy-six vertebrae were divided into 2 groups. Each vertebra was given a number from 1 to 76 . Two researchers were included in the pedicle screw placement stage. In the first group of vertebra (from 1 to 38 ) in group 1, pedicle screws were inserted by only one researcher (practitioner) under the supervision of the other researcher (supervisor). In the remaining vertebrae (from 39 to 76 ) in group 2, the researchers changed their positions.

The first 19 of 38 vertebrae in group 1 (Group 1a) were placed and fixed in vice as their endplates (superior and inferior surfaces) became parallel to vice mouths respectively (Figure 2 $A, B)$. The right SPSTL of the first vertebra was perpendicular to the horizontal plane. The procedure continued by reducing the previous angle by 5 degrees in each following vertebra until the last $19^{\text {th }}$ vertebra's SPSTL was parallel to the horizontal plane. In group 1a, following each fixation in which the right SPSTL was at the desired angulation position with the horizontal plane, the craniocaudal angulation (CCA) in the sagittal plane and lateromedial angulation (LMA) in the horizontal plane of the bilateral pedicle screws' trajectories were calculated manually based on bilateral LPSTL and SPSTL by the supervisor. Under the guidance of the supervisor, these measurements were told to the practitioner in order to place the screws according to those values by using the smartphone app.

Following the first stage of the procedure, the second 19 of the 38 vertebrae in the first group (Group 1b), numbered from 20 to 38, were placed in the vice as their endplates became perpendicular to the vice mouths respectively (Figure 2C, D). Nineteen vertebral bodies were fixed respectively as the right LPSTL of the $20^{\text {th }}$ vertebra was perpendicular to the horizontal plane and the following vertebrae were fixed by reducing the previous angle by 5 degrees until the right LPSTL of the $38^{\text {th }}$ vertebra was parallel to the horizontal plane as in the previous subgroup. The same method was followed and the same procedures applied at each stage.

It was planned to test the sensitivity of the app's angle measuring in the axial plane in the first subgroup (Group 1a) and in the sagittal plane in the second subgroup (Group 1b) by this mechanical design.
The same procedures were completed within the same technical and methodological principles in the second subgroups (Group 2a and 2b). Contrary to the previous stages, the practitioner and supervisor were shifted and practitioner who was previously the supervisor in group 1 inserted the pedicle screws.

The mobile app which constitutes the research topic of our study, the Angle-Meter (Free) smartphone application, is introduced as an accurate angle measurement tool. It was developed by Jin Jeon and can be downloaded free of charge from the Apple (CA, USA) store to iOS devices (https://itunes. apple.com/tr/app/angle-meter/id430292666?mt=8).

Two angles can be measured by the smartphone using this app: 1) The angle between the ground (horizontal plane) and the screen or back of the device in the anterior-posterior direction, 2) The angle between the ground (horizontal plane) and the lateral border (the border just near the corner) of the device in the left-right direction.

In the practice stage of our study, the corner of the smartphone was placed just above the insertion point (Figure 3A). The screen of the smartphone was placed parallel to the horizontal plane. In this position, movement of the smartphone anteriorly or posteriorly showed the CCA; right or left movement showed the LMA (Figure 3A, B). According to the determined trajectory angles using the angle-meter application, the defined angles were displayed on the smartphone screen by placing it in an appropriate position, and the screw was inserted following the long border of the smartphone (Figure $3 \mathrm{~A}-\mathrm{C}$ ).

While the angle-meter app was working actively, the smartphone was brought closer to the awl, pedicle probe and screw holder respectively. All screw insertions were performed by a single researcher (practitioner). The supervisor fixed each vertebra in the vice and only showed the insertion points to the practitioner and later the working zone was closed. According to the previously measured and defined angles, pedicle screws were inserted from previously defined entry points by viewing the specified angles on the screen.

Pedicle breach was evaluated according to gross observation. Additionally, the accuracy of the app-guided pedicle screw
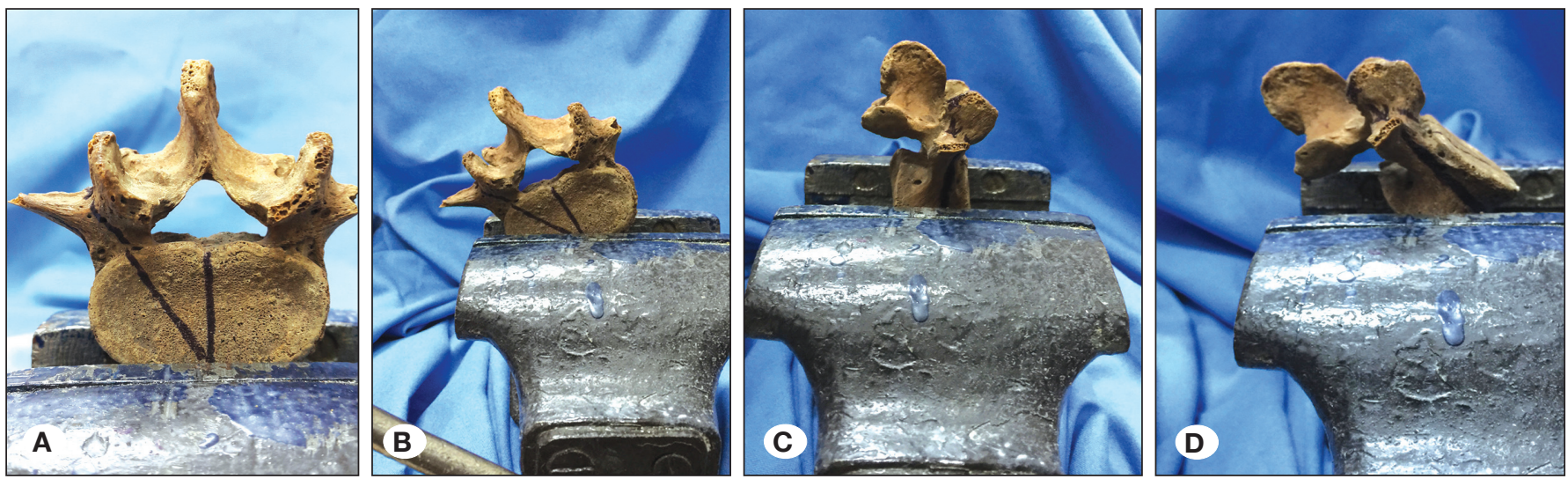

Figure 2: A) Horizontal fixation of the vertebra by vice. B) Angulation and displacement of the fixed vertebra in horizontal plane. C) Fixation of the vertebra by vice in sagittal plane. D) Angulation and displacement of the fixed vertebra in sagittal plane. 
placement technique was assessed by CT scans of each vertebra after the procedure. Radiopaque silicone yarns were glued to these lines before radiological investigation (Figure $4 A$, B). Each vertebra underwent thin-slice CT imaging. Three-dimensional reconstruction images of these vertebrae were created by using the OsiriX software (Pixmeo, SARL,
Switzerland)(Figure 5A, B). Subsequently, after converting cortical bony structures to transparent structures, the inner bony parts were removed radiologically and only the outer limits of the vertebra, silicone yarns and screws were preserved (Figure 6A-D). From the lateral and superior views, the differences between silicone yarns and screws were
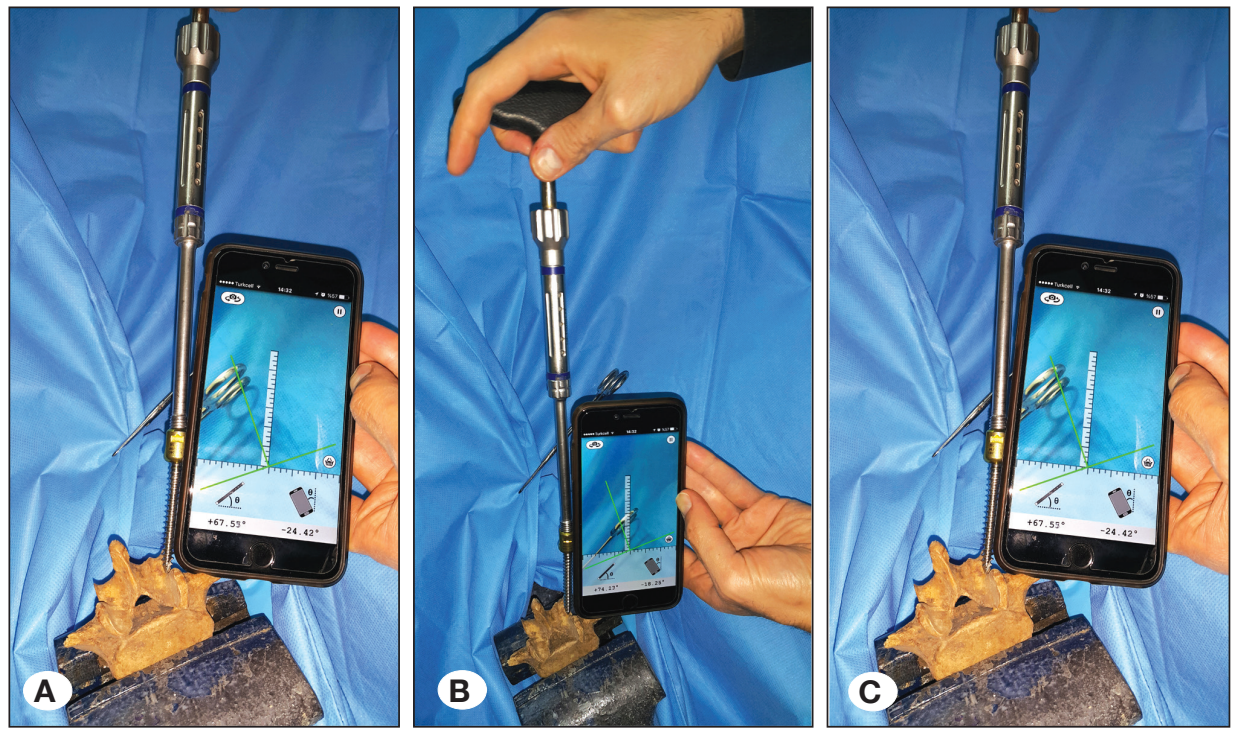

Figure 3: Pedicle screw insertion in the guidance of smartphone. After showing the insertion point to the practitioner, the working area is closed and proper angulations are provided in the guidance of Angle-Meter app.

A) Placing the corner of the smartphone just above the defined insertion point. B) Positioning the screw holder according to the proper craniocaudal angulation. C) Lateromedial angulation and displacement of smartphone and screw holder.
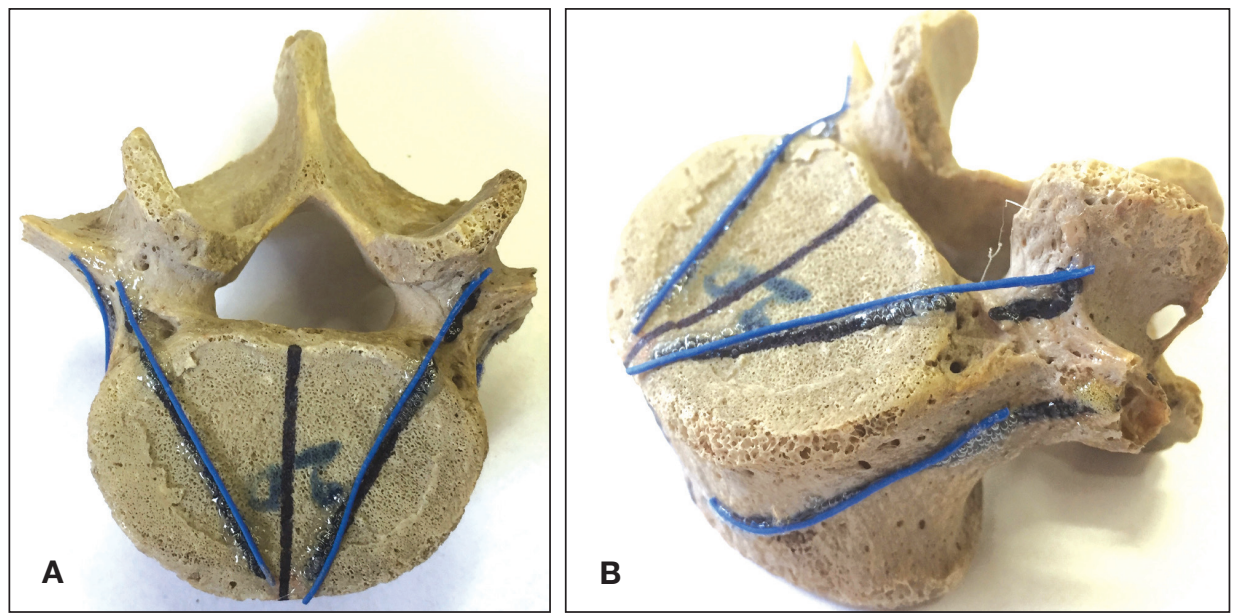

Figure 4: Radiopaque silicone yarns were glued bilateral SPSTLs over the superior aspect of vertebral body (A) and LPSTL over the lateral aspect of vertebral body (B).
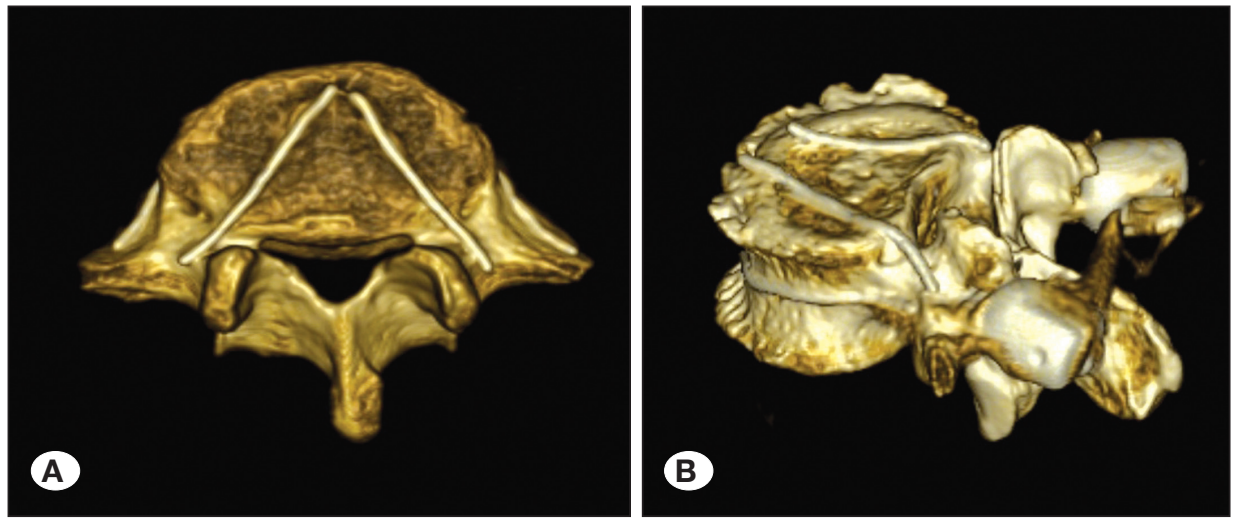

Figure 5: Three-dimensional reconstruction $\mathrm{CT}$ images of the vertebra from superior (A) and oblique (B) views in which glued silicone yarns are clearly distinguished. 
evaluated and measured in terms of their angulations and anatomical relationships (Figure 7A, B).

\section{Anatomical Specimens}

During selection of dry vertebrae for screw insertion, there were exclusion criteria such as any signs of previous operation, destruction of vertebrae, or vertebrae with anatomica variations and pathological congenital anomalies. Eighteen vertebrae were broken during pedicle insertion or fixation with vice due to osteoporotic feature and overload and all these were excluded from our study.

\section{Statistical Analysis}

All data were analyzed by the SPSS 11.5 software package for Windows. Measured data were expressed as mean \pm standard deviation. The two-sample t-test was used to check
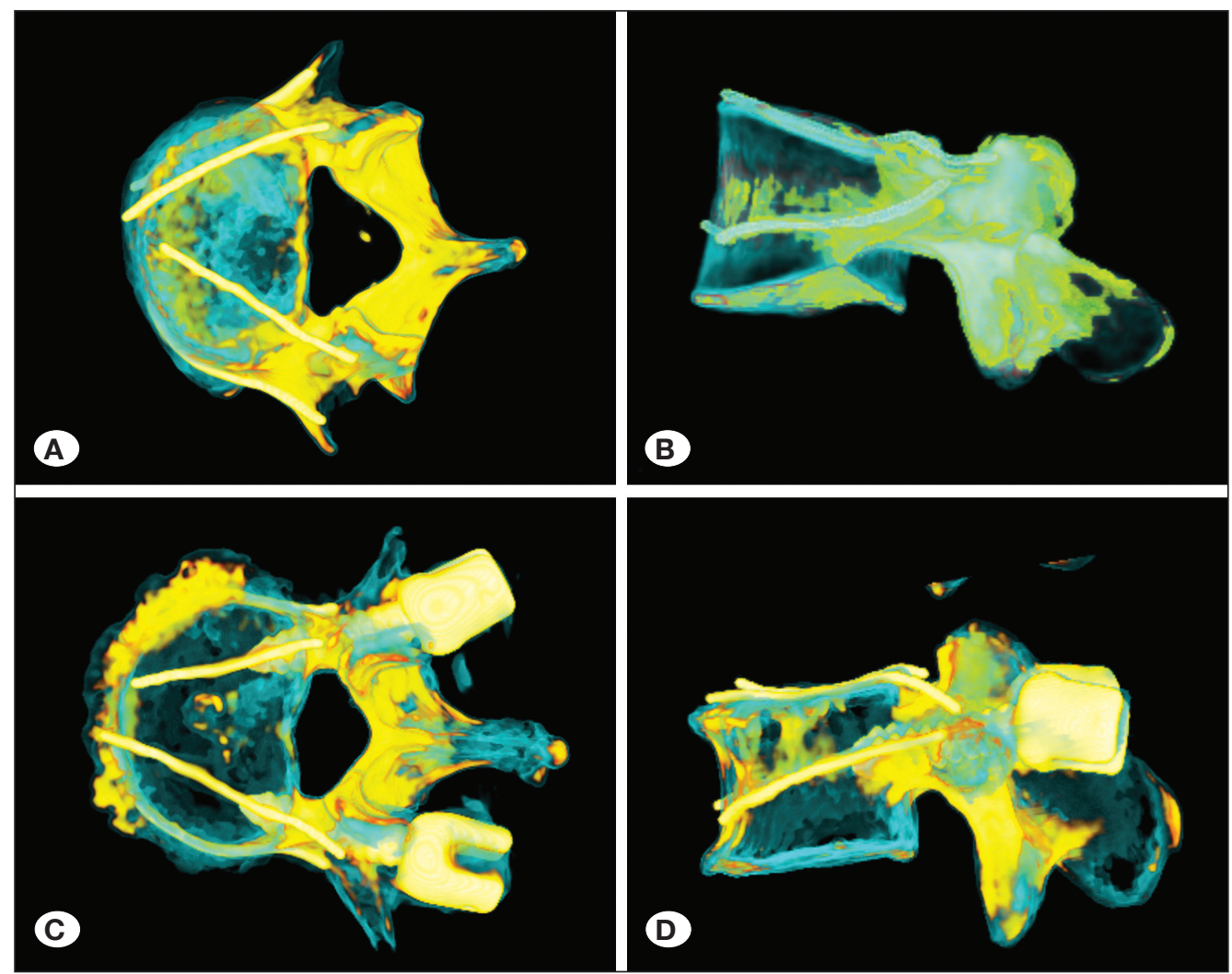

Figure 6: Radiologically transparent vertebral body before (A, B) and after (C, D) pedicle screw insertion.
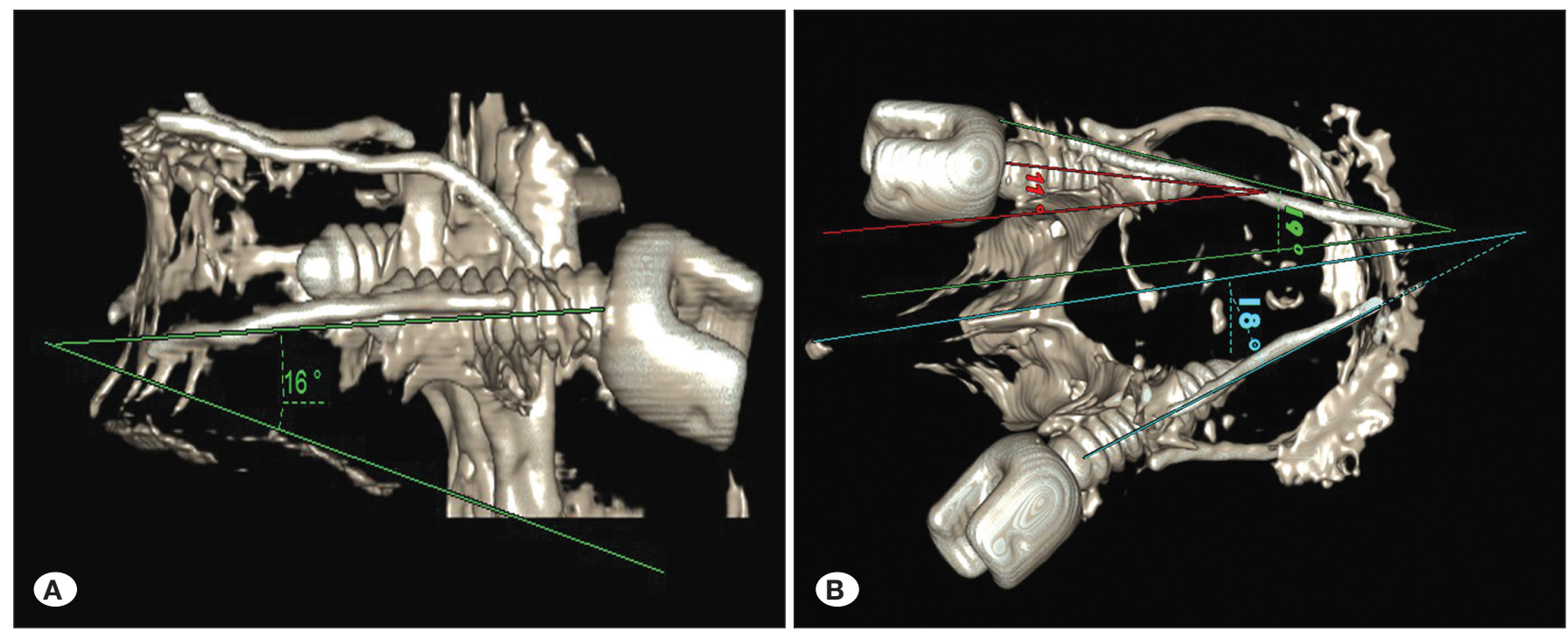

Figure 7: Superimposed of pedicle screws and silicone yarns in lateral view (A), and superior view (B), and their angulations with midline and each other. 
for statistically significant differences between the groups. For all analyses, statistical significance was determined at a value of $p<0.05$.

\section{RESULTS}

The mean deviation of 76 pedicle screws on the right side was $2.30^{\circ} \pm 1.78^{\circ}$ in the horizontal plane and $2.17^{\circ} \pm 1.57^{\circ}$ in the sagittal plane and on the left side $3.01^{\circ} \pm 1.83^{\circ}$ in the horizontal plane and $2.38^{\circ} \pm 1.68^{\circ}$ in the sagittal plane (Table I). According to the t-test results, there were significant differences between the two groups in the craniocaudal direction of the right side pedicle screws $(p=0.049)$ and in the craniocaudal direction of the left side pedicle screws $(\mathrm{p}=0.010)$.

The measured degrees of LMA and CCA in group 1 and group 2 prior to each procedure are shown in Table II and Table III respectively. Furthermore, the amount of deviation degree of pedicle screws according to the axis of silicone yarns were also shown below these values in these tables (in the second line for each vertebra).

None of the screws showed any vertebral body wall or canal penetration from the lateral or medial side of the vertebra. For each vertebra, time for bilateral insertion of the pedicle screws was approximately 12-16 minutes.

The dataset contains observations of 2 angulations of each of the 152 pedicle screws in 2 groups. For each observation, we measured the degree of deviation of the inserted screws according to the previously defined trajectory lines that were marked with radiopaque fibers in the sagittal and horizontal planes.

According to the t-test results, there was no statistically significant difference in the right pedicle LMA scores between group $1(M=2.026, S D=0.208)$ and group $2(M=2.579$, $\mathrm{SD}=0.351), \mathrm{p}=0.180$. Similarly, there was no statistically significant difference in left pedicle LMA scores between group $1(\mathrm{M}=2.684, \mathrm{SD}=.233)$ and group $2(\mathrm{M}=3.342, \mathrm{SD}=0.346)$, $\mathrm{p}=0.120$.

On the other hand, there was a statistically significant difference between the two groups in the right pedicle (CCA), group $1(M=2.526, S D=0.249)$ and group $2(M=1.816$, $S D=0.253),(p=0.049)$. There was also a significant difference in the left pedicle (CCA), group $1(\mathrm{M}=2.868, \mathrm{SD}=0.285)$ and group $2(\mathrm{M}=1.895, \mathrm{SD}=0.238),(\mathrm{p}=0.010)$.

There was no significant differences between groups $1 \mathrm{a}$ and $1 b$ in the Right Pedicle (LMA) $(p=0.1799)$ and in the right pedicle (CCA) $(p=0.056)$; however, groups $1 a$ and $1 b$ scored differently on other measures (Table IV). For left pedicle LMA, the difference between the groups was statistically significant $(p=0.040)$. Also, there was a statistically significant difference between groups $1 a$ and $1 b$ in the left pedicle CCA, $(p=0.019)$.

Among groups $2 \mathrm{a}$ and $2 \mathrm{~b}$, there was a statistically significant difference only for the right pedicle LMA, $p=0.01$. We did not observe statistically significant differences for other measures such as the left pedicle LMA, right pedicle CCA, or left pedicle CCA.

Additionally, there was a statistically significant difference between group 1a right CCA and group 1b right LMA values $(p=0.0247)$, whereas no difference was seen between group $2 a$ right CCA and group $2 b$ right LMA values $(p=0.1778)$.

\section{DISCUSSION}

Hand-held computer technology (smartphones, tablet computers) is expanding its target audience through original software for itself day by day. These applications are designed for various purposes in different categories. These technological innovations and improvements are becoming an important and indispensable part of individuals' everyday life. There are useful applications providing personal assistance not only in social life, but also in business life. Medicine is also another important sector that is affected from this trend in a positive way. Medical applications could become useful in applied health branches via these portable smart devices. It was reported that medical students tend to use the mobile applications that serve as guides for diagnosis and medication, whereas physicians use medical calculators (11).

Another advantage of this method that could be mentioned is easy positioning on vertebrae. In some extreme positions of the vertebrae, the screen may be placed parallel to the midline. The anterior and posterior movement of the smartphone then detects the lateral medial angulation while the right or left movement detects craniocaudal angulation.

While the newly developed devices were huge and impractical in their initial use in surgical procedures, they gradually became much smaller with increased frequency and period of use. Just as today's hand-held computers have replaced the cumbersome computers of the 1980's, the use of tablet computers or smartphones in surgeries instead of CTintegrated neuronavigation systems should not be surprising. However, while medical apps in the neurosurgery category find themselves a place in a wide range of content related to diagnosis, surgical clinician education, journal access, and preoperative management of patients, there is still no app

Table I: Measured Angle Deviation and Their Mean and Standard Deviations

\begin{tabular}{cccccc}
\hline Variable & Obs & Mean & SD & Min & Max \\
\hline Right LMA & 76 & 2.302632 & 1.789001 & 0 & 8 \\
\hline Right CCA & 76 & 2.171053 & 1.578085 & 0 & 6 \\
\hline Left LMA & 76 & 3.013158 & 1.836616 & 0 & 8 \\
\hline Left CCA & 76 & 2.381579 & 1.681008 & 0 & 6 \\
\hline
\end{tabular}


to guide the surgeon in any part of the surgical intervention legally and medically.

Considering all technologic contributions to the spinal industry and the well-planned neuroanatomic studies focused on safe and correct screw insertion technique, spine surgeons are still in search of a fast and perfect pedicle screw placement method $(7,8,10,12,14,15)$. Among all the previously used methods, the balance has always deteriorated in favor of quickness or perfection (17).

In the literature, the potential interaction of medical apps with compatible devices and the rate of use of such apps installed on hand-held computers in surgical procedures are still below

Table II: First Practitioner's Characteristics (Measured Trajectory Lines and Angulations) of Each Vertebra (Upper Line) and Angulations of Pedicle Screws After the Procedure (Lower Line)

\begin{tabular}{|c|c|c|c|c|c|c|c|c|c|}
\hline Vertebra & $\begin{array}{l}\text { Right Ped. } \\
\text { (LMA) }\end{array}$ & $\begin{array}{l}\text { Right Ped. } \\
\text { (CCA) }\end{array}$ & $\begin{array}{l}\text { Left Ped. } \\
\text { (LMA) }\end{array}$ & $\begin{array}{l}\text { Left Ped. } \\
\text { (CCA) }\end{array}$ & Vertebra & $\begin{array}{l}\text { Right Ped. } \\
\text { (CCA) }\end{array}$ & $\begin{array}{l}\text { Right Ped. } \\
\text { (LMA) }\end{array}$ & $\begin{array}{l}\text { Left Ped. } \\
\text { (CCA) }\end{array}$ & $\begin{array}{l}\text { Left Ped. } \\
\text { (LMA) }\end{array}$ \\
\hline 1 & $\begin{array}{l}90^{\circ} \\
\mathrm{L} 2^{\circ}\end{array}$ & $\begin{array}{l}10^{\circ} \\
13^{\circ}\end{array}$ & $\begin{array}{l}50^{\circ} \\
\mathrm{M} 4^{\circ}\end{array}$ & $\begin{array}{l}10^{\circ} \\
\mathrm{S} 2^{\circ}\end{array}$ & 20 & $\begin{array}{c}90^{\circ} \\
0^{\circ} \\
\end{array}$ & $\begin{array}{l}16^{\circ} \\
L 11^{\circ} \\
\end{array}$ & $\begin{array}{l}90^{\circ} \\
\mathrm{S} 1^{\circ} \\
\end{array}$ & $\begin{array}{l}16^{\circ} \\
\mathrm{L} 2^{\circ} \\
\end{array}$ \\
\hline 2 & $\begin{array}{r}85^{\circ} \\
\mathrm{L} 2^{\circ} \\
\end{array}$ & $\begin{array}{l}12^{\circ} \\
\mathrm{S} 1^{\circ}\end{array}$ & $\begin{array}{l}37^{\circ} \\
M 5^{\circ} \\
\end{array}$ & $\begin{array}{l}12^{\circ} \\
14^{\circ} \\
\end{array}$ & 21 & $\begin{array}{l}85^{\circ} \\
\mathrm{S} 1^{\circ} \\
\end{array}$ & $\begin{array}{r}11^{\circ} \\
M 1^{\circ} \\
\end{array}$ & $\begin{array}{l}85^{\circ} \\
11^{\circ} \\
\end{array}$ & $\begin{array}{r}11^{\circ} \\
M 2^{\circ}\end{array}$ \\
\hline 3 & $\begin{array}{c}80^{\circ} \\
0^{\circ} \\
\end{array}$ & $\begin{array}{l}15^{\circ} \\
12^{\circ} \\
\end{array}$ & $\begin{array}{l}22^{\circ} \\
\mathrm{M} 4^{\circ} \\
\end{array}$ & $\begin{array}{l}15^{\circ} \\
14^{\circ} \\
\end{array}$ & 22 & $\begin{array}{l}80^{\circ} \\
11^{\circ} \\
\end{array}$ & $\begin{array}{r}35^{\circ} \\
M 1^{\circ} \\
\end{array}$ & $\begin{array}{l}80^{\circ} \\
12^{\circ} \\
\end{array}$ & $\begin{array}{l}35^{\circ} \\
\mathrm{L} 2^{\circ} \\
\end{array}$ \\
\hline 4 & $\begin{array}{r}75^{\circ} \\
M 1^{\circ} \\
\end{array}$ & $\begin{array}{l}19^{\circ} \\
12^{\circ} \\
\end{array}$ & $\begin{array}{r}75^{\circ} \\
\mathrm{L} 1^{\circ} \\
\end{array}$ & $\begin{array}{l}19^{\circ} \\
12^{\circ} \\
\end{array}$ & 23 & $\begin{array}{l}75^{\circ} \\
S 2^{\circ} \\
\end{array}$ & $\begin{array}{l}23^{\circ} \\
M 2^{\circ}\end{array}$ & $\begin{array}{l}75^{\circ} \\
0^{\circ} \\
\end{array}$ & $\begin{array}{l}23^{\circ} \\
\mathrm{L} 1^{\circ} \\
\end{array}$ \\
\hline 5 & $\begin{array}{l}70^{\circ} \\
\mathrm{L} 2^{\circ} \\
\end{array}$ & $\begin{array}{l}10^{\circ} \\
11^{\circ}\end{array}$ & $\begin{array}{l}78^{\circ} \\
\mathrm{M} 2^{\circ} \\
\end{array}$ & $\begin{array}{l}10^{\circ} \\
12^{\circ}\end{array}$ & 24 & $\begin{array}{l}70^{\circ} \\
S 3^{\circ} \\
\end{array}$ & $\begin{array}{l}34^{\circ} \\
\mathrm{M} 3^{\circ} \\
\end{array}$ & $\begin{array}{l}70^{\circ} \\
13^{\circ} \\
\end{array}$ & $\begin{array}{l}34^{\circ} \\
\mathrm{M} 2^{\circ}\end{array}$ \\
\hline 6 & $\begin{array}{l}65^{\circ} \\
\mathrm{L} 1^{\circ} \\
\end{array}$ & $\begin{array}{l}8^{\circ} \\
13^{\circ} \\
\end{array}$ & $\begin{array}{l}39^{\circ} \\
\mathrm{L} 2^{\circ} \\
\end{array}$ & $\begin{array}{l}8^{\circ} \\
15^{\circ} \\
\end{array}$ & 25 & $\begin{array}{l}65^{\circ} \\
12^{\circ}\end{array}$ & $\begin{array}{l}33^{\circ} \\
\mathrm{L} 4^{\circ} \\
\end{array}$ & $\begin{array}{l}65^{\circ} \\
13^{\circ}\end{array}$ & $\begin{array}{l}33^{\circ} \\
M 2^{\circ}\end{array}$ \\
\hline 7 & $\begin{array}{l}60^{\circ} \\
\mathrm{M} 4^{\circ}\end{array}$ & $\begin{array}{l}15^{\circ} \\
S 2^{\circ} \\
\end{array}$ & $\begin{array}{l}86^{\circ} \\
M 2^{\circ} \\
\end{array}$ & $\begin{array}{l}15^{\circ} \\
13^{\circ}\end{array}$ & 26 & $\begin{array}{l}60^{\circ} \\
13^{\circ} \\
\end{array}$ & $\begin{array}{l}36^{\circ} \\
\mathrm{M} 2^{\circ} \\
\end{array}$ & $\begin{array}{l}60^{\circ} \\
13^{\circ}\end{array}$ & $\begin{array}{l}36^{\circ} \\
\mathrm{L} 1^{\circ} \\
\end{array}$ \\
\hline 8 & $\begin{array}{l}55^{\circ} \\
\mathrm{L} 4^{\circ} \\
\end{array}$ & $\begin{array}{l}14^{\circ} \\
S 4^{\circ} \\
\end{array}$ & $\begin{array}{l}97^{\circ} \\
\mathrm{L} 2^{\circ} \\
\end{array}$ & $\begin{array}{l}14^{\circ} \\
S 2^{\circ} \\
\end{array}$ & 27 & $\begin{array}{l}55^{\circ} \\
\mathrm{S} 1^{\circ} \\
\end{array}$ & $\begin{array}{l}6^{\circ} \\
M 1^{\circ}\end{array}$ & $\begin{array}{r}55^{\circ} \\
0^{\circ} \\
\end{array}$ & $\begin{array}{l}6^{\circ} \\
0^{\circ} \\
\end{array}$ \\
\hline 9 & $\begin{array}{r}50^{\circ} \\
M 1^{\circ} \\
\end{array}$ & $\begin{array}{l}6^{\circ} \\
15^{\circ} \\
\end{array}$ & $\begin{array}{l}126^{\circ} \\
\mathrm{M} 4^{\circ} \\
\end{array}$ & $\begin{array}{l}6^{\circ} \\
16^{\circ} \\
\end{array}$ & 28 & $\begin{array}{l}50^{\circ} \\
11^{\circ} \\
\end{array}$ & $\begin{array}{l}9^{\circ} \\
M 1^{\circ}\end{array}$ & $\begin{array}{l}50^{\circ} \\
12^{\circ} \\
\end{array}$ & $\begin{array}{l}9^{\circ} \\
\mathrm{M}^{\circ} \\
\end{array}$ \\
\hline 10 & $\begin{array}{r}45^{\circ} \\
\mathrm{M}^{\circ} \\
\end{array}$ & $\begin{array}{l}5^{\circ} \\
14^{\circ} \\
\end{array}$ & $\begin{array}{l}59^{\circ} \\
\mathrm{L} 4^{\circ} \\
\end{array}$ & $\begin{array}{l}5^{\circ} \\
S 2^{\circ} \\
\end{array}$ & 29 & $\begin{array}{l}45^{\circ} \\
\mathrm{S} 1^{\circ} \\
\end{array}$ & $\begin{array}{r}37^{\circ} \\
M 2^{\circ} \\
\end{array}$ & $\begin{array}{l}45^{\circ} \\
S 6^{\circ} \\
\end{array}$ & $\begin{array}{l}37^{\circ} \\
0^{\circ} \\
\end{array}$ \\
\hline 11 & $\begin{array}{r}40^{\circ} \\
\mathrm{M} 1^{\circ} \\
\end{array}$ & $\begin{array}{l}12^{\circ} \\
11^{\circ} \\
\end{array}$ & $\begin{array}{l}90^{\circ} \\
\mathrm{L} 2^{\circ}\end{array}$ & $\begin{array}{l}12^{\circ} \\
15^{\circ} \\
\end{array}$ & 30 & $\begin{array}{l}40^{\circ} \\
\mathrm{S} 1^{\circ}\end{array}$ & $\begin{array}{c}33^{\circ} \\
0^{\circ} \\
\end{array}$ & $\begin{array}{l}40^{\circ} \\
11^{\circ} \\
\end{array}$ & $\begin{array}{l}33^{\circ} \\
M 4^{\circ} \\
\end{array}$ \\
\hline 12 & $\begin{array}{r}35^{\circ} \\
M 2^{\circ} \\
\end{array}$ & $\begin{array}{l}10^{\circ} \\
11^{\circ} \\
\end{array}$ & $\begin{array}{l}125^{\circ} \\
\mathrm{L} 3^{\circ} \\
\end{array}$ & $\begin{array}{l}10^{\circ} \\
16^{\circ} \\
\end{array}$ & 31 & $\begin{array}{l}35^{\circ} \\
13^{\circ}\end{array}$ & $\begin{array}{l}50^{\circ} \\
M 1^{\circ} \\
\end{array}$ & $\begin{array}{l}35^{\circ} \\
12^{\circ} \\
\end{array}$ & $\begin{array}{r}50^{\circ} \\
\mathrm{M}^{\circ} \\
\end{array}$ \\
\hline 13 & $\begin{array}{l}30^{\circ} \\
\mathrm{M} 1^{\circ} \\
\end{array}$ & $\begin{array}{l}10^{\circ} \\
13^{\circ} \\
\end{array}$ & $\begin{array}{l}126^{\circ} \\
\mathrm{M} 1^{\circ}\end{array}$ & $\begin{array}{l}10^{\circ} \\
12^{\circ} \\
\end{array}$ & 32 & $\begin{array}{l}30^{\circ} \\
\mathrm{S} 4^{\circ}\end{array}$ & $\begin{array}{c}5^{\circ} \\
\mathrm{M}^{\circ}\end{array}$ & $\begin{array}{l}30^{\circ} \\
\mathrm{S} 3^{\circ}\end{array}$ & $\begin{array}{c}5^{\circ} \\
\mathrm{M}^{\circ} \\
\end{array}$ \\
\hline 14 & $\begin{array}{l}25^{\circ} \\
M 2^{\circ}\end{array}$ & $\begin{array}{l}14^{\circ} \\
13^{\circ} \\
\end{array}$ & $\begin{array}{l}139^{\circ} \\
M 7^{\circ}\end{array}$ & $\begin{array}{l}14^{\circ} \\
\mathrm{S} 3^{\circ}\end{array}$ & 33 & $\begin{array}{l}25^{\circ} \\
\mathrm{S} 5^{\circ} \\
\end{array}$ & $\begin{array}{r}4^{\circ} \\
\mathrm{M}^{\circ} \\
\end{array}$ & $\begin{array}{l}25^{\circ} \\
\mathrm{S} 4^{\circ}\end{array}$ & $\begin{array}{r}4^{\circ} \\
\mathrm{M}^{\circ} \\
\end{array}$ \\
\hline 15 & $\begin{array}{l}20^{\circ} \\
\mathrm{M} 6^{\circ}\end{array}$ & $\begin{array}{c}8^{\circ} \\
16^{\circ} \\
\end{array}$ & $\begin{array}{l}132^{\circ} \\
\mathrm{L} 3^{\circ}\end{array}$ & $\begin{array}{l}8^{\circ} \\
15^{\circ} \\
\end{array}$ & 34 & $\begin{array}{l}20^{\circ} \\
\mathrm{S} 2^{\circ}\end{array}$ & $\begin{array}{l}31^{\circ} \\
{\mathrm{M} 2^{\circ}}^{\circ}\end{array}$ & $\begin{array}{l}20^{\circ} \\
14^{\circ}\end{array}$ & $\begin{array}{l}31^{\circ} \\
\mathrm{M}^{\circ}\end{array}$ \\
\hline 16 & $\begin{array}{r}15^{\circ} \\
\mathrm{M}^{\circ} \\
\end{array}$ & $\begin{array}{l}10^{\circ} \\
13^{\circ} \\
\end{array}$ & $\begin{array}{l}87^{\circ} \\
\angle 3^{\circ} \\
\end{array}$ & $\begin{array}{l}10^{\circ} \\
S 2^{\circ} \\
\end{array}$ & 35 & $\begin{array}{l}15^{\circ} \\
14^{\circ} \\
\end{array}$ & $\begin{array}{r}7^{\circ} \\
M 2^{\circ} \\
\end{array}$ & $\begin{array}{l}15^{\circ} \\
15^{\circ}\end{array}$ & $\begin{array}{c}7^{\circ} \\
\mathrm{M} 4^{\circ}\end{array}$ \\
\hline 17 & $\begin{array}{l}10^{\circ} \\
\mathrm{M} 2^{\circ} \\
\end{array}$ & $\begin{array}{l}80^{\circ} \\
14^{\circ} \\
\end{array}$ & $\begin{array}{l}112^{\circ} \\
\mathrm{M} 2^{\circ} \\
\end{array}$ & $\begin{array}{l}80^{\circ} \\
16^{\circ} \\
\end{array}$ & 36 & $\begin{array}{l}10^{\circ} \\
\mathrm{S} 2^{\circ}\end{array}$ & $\begin{array}{l}3^{\circ} \\
M^{\circ} \\
\end{array}$ & $\begin{array}{l}10^{\circ} \\
11^{\circ} \\
\end{array}$ & $\begin{array}{l}3^{\circ} \\
\mathrm{M}^{\circ} \\
\end{array}$ \\
\hline 18 & $\begin{array}{l}5^{\circ} \\
{\mathrm{M} 2^{\circ}}^{\circ} \\
\end{array}$ & $\begin{array}{r}9^{\circ} \\
16^{\circ} \\
\end{array}$ & $\begin{array}{l}113^{\circ} \\
\mathrm{L} 5^{\circ} \\
\end{array}$ & $\begin{array}{c}9^{\circ} \\
14^{\circ}\end{array}$ & 37 & $\begin{array}{r}5^{\circ} \\
13^{\circ} \\
\end{array}$ & $\begin{array}{l}39^{\circ} \\
\mathrm{M} 5^{\circ} \\
\end{array}$ & $\begin{array}{c}5^{\circ} \\
\mathrm{S} 1^{\circ} \\
\end{array}$ & $\begin{array}{r}39^{\circ} \\
\mathrm{M} 2^{\circ} \\
\end{array}$ \\
\hline 19 & $\begin{array}{c}0^{\circ} \\
M 1^{\circ} \\
\end{array}$ & $\begin{array}{r}5^{\circ} \\
13^{\circ} \\
\end{array}$ & $\begin{array}{l}116^{\circ} \\
\mathrm{M} 4^{\circ} \\
\end{array}$ & $\begin{array}{r}5^{\circ} \\
12^{\circ} \\
\end{array}$ & 38 & $\begin{array}{l}0^{\circ} \\
0^{\circ}\end{array}$ & $\begin{array}{r}19^{\circ} \\
{\mathrm{M} 2^{\circ}}^{\circ} \\
\end{array}$ & $\begin{array}{l}0^{\circ} \\
0^{\circ}\end{array}$ & $\begin{array}{r}19^{\circ} \\
\left\llcorner 3^{\circ}\right. \\
\end{array}$ \\
\hline
\end{tabular}

L: Lateral, M: Medial, S: Superior, I: Inferior shows the direction of the deviation of each screw. CCA: Craniocaudal angulation, LMA: Lateromedial angulation, Ped: Pedicle. 
expectations. Although there is a satisfactory number of domains and surgical disciplines in medicine to generate and use new apps, these devices have commonly been used in and focused on orthopaedic surgery, general surgery and ear, nose and throat surgery (9). In the neurosurgical field, external ventricular catheter placement and localization of superficial cerebral lesions constitute the main topics in app guided procedures (1-3).

Despite the overall achievement of the presented app on an anatomical vertebra dry bone model, we experienced unexpected difficulties during procedure. As we described

Table III: Second Practitioner's Characteristics of Each Vertebra (Upper Line) and Angulations of Pedicle Screws After the Procedure (Lower Line)

\begin{tabular}{|c|c|c|c|c|c|c|c|c|c|}
\hline Vertebra & $\begin{array}{l}\text { Right Ped. } \\
\text { (LMA) }\end{array}$ & $\begin{array}{l}\text { Right Ped. } \\
\text { (CCA) }\end{array}$ & $\begin{array}{l}\text { Left Ped. } \\
\text { (LMA) }\end{array}$ & $\begin{array}{l}\text { Left Ped. } \\
\text { (CCA) }\end{array}$ & Vertebra & $\begin{array}{l}\text { Right Ped. } \\
\text { (CCA) }\end{array}$ & $\begin{array}{l}\text { Right Ped. } \\
\text { (LMA) }\end{array}$ & $\begin{array}{l}\text { Left Ped. } \\
\text { (CCA) }\end{array}$ & $\begin{array}{l}\text { Left Ped. } \\
\text { (LMA) }\end{array}$ \\
\hline 39 & $\begin{array}{l}90^{\circ} \\
\mathrm{L} 4^{\circ} \\
\end{array}$ & $\begin{array}{l}17^{\circ} \\
S 3^{\circ}\end{array}$ & $\begin{array}{l}43^{\circ} \\
M 5^{\circ}\end{array}$ & $\begin{array}{l}17^{\circ} \\
12^{\circ}\end{array}$ & 58 & $\begin{array}{l}90^{\circ} \\
0^{\circ}\end{array}$ & $\begin{array}{l}38^{\circ} \\
0^{\circ}\end{array}$ & $\begin{array}{l}90^{\circ} \\
S 1^{\circ} \\
\end{array}$ & $\begin{array}{r}38^{\circ} \\
\mathrm{L} 1^{\circ} \\
\end{array}$ \\
\hline 40 & $\begin{array}{r}85^{\circ} \\
\mathrm{L} 3^{\circ} \\
\end{array}$ & $\begin{array}{l}23^{\circ} \\
12^{\circ}\end{array}$ & $\begin{array}{l}41^{\circ} \\
0^{\circ} \\
\end{array}$ & $\begin{array}{l}23^{\circ} \\
S 2^{\circ} \\
\end{array}$ & 59 & $\begin{array}{l}85^{\circ} \\
12^{\circ}\end{array}$ & $\begin{array}{l}16^{\circ} \\
L 11^{\circ} \\
\end{array}$ & $\begin{array}{l}85^{\circ} \\
0^{\circ} \\
\end{array}$ & $\begin{array}{c}16^{\circ} \\
0^{\circ} \\
\end{array}$ \\
\hline 41 & $\begin{array}{l}80^{\circ} \\
0^{\circ}\end{array}$ & $\begin{array}{l}15^{\circ} \\
13^{\circ}\end{array}$ & $\begin{array}{l}22^{\circ} \\
0^{\circ}\end{array}$ & $\begin{array}{l}15^{\circ} \\
S 2^{\circ}\end{array}$ & 60 & $\begin{array}{l}80^{\circ} \\
0^{\circ}\end{array}$ & $\begin{array}{l}28^{\circ} \\
M 1^{\circ}\end{array}$ & $\begin{array}{l}80^{\circ} \\
12^{\circ}\end{array}$ & $\begin{array}{l}28^{\circ} \\
M 1^{\circ}\end{array}$ \\
\hline 42 & $\begin{array}{l}75^{\circ} \\
M 2^{\circ}\end{array}$ & $\begin{array}{l}31^{\circ} \\
S 2^{\circ}\end{array}$ & $\begin{array}{l}75^{\circ} \\
M 1^{\circ}\end{array}$ & $\begin{array}{l}31^{\circ} \\
12^{\circ}\end{array}$ & 61 & $\begin{array}{l}75^{\circ} \\
S 2^{\circ}\end{array}$ & $\begin{array}{l}35^{\circ} \\
\mathrm{L} 2^{\circ}\end{array}$ & $\begin{array}{c}75^{\circ} \\
0^{\circ}\end{array}$ & $\begin{array}{l}35^{\circ} \\
M 2^{\circ}\end{array}$ \\
\hline 43 & $\begin{array}{l}70^{\circ} \\
\mathrm{L} 1^{\circ}\end{array}$ & $\begin{array}{l}13^{\circ} \\
\mathrm{S} 2^{\circ}\end{array}$ & $\begin{array}{l}73^{\circ} \\
M 3^{\circ}\end{array}$ & $\begin{array}{l}13^{\circ} \\
0^{\circ}\end{array}$ & 62 & $\begin{array}{l}70^{\circ} \\
11^{\circ}\end{array}$ & $\begin{array}{l}23^{\circ} \\
\mathrm{M} 3^{\circ} \\
\end{array}$ & $\begin{array}{l}70^{\circ} \\
S 2^{\circ} \\
\end{array}$ & $\begin{array}{l}23^{\circ} \\
M 2^{\circ}\end{array}$ \\
\hline 44 & $\begin{array}{l}65^{\circ} \\
\mathrm{L} 2^{\circ} \\
\end{array}$ & $\begin{array}{l}12^{\circ} \\
11^{\circ} \\
\end{array}$ & $\begin{array}{l}32^{\circ} \\
\mathrm{M} 4^{\circ}\end{array}$ & $\begin{array}{l}12^{\circ} \\
S 2^{\circ}\end{array}$ & 63 & $\begin{array}{l}65^{\circ} \\
12^{\circ}\end{array}$ & $\begin{array}{c}30^{\circ} \\
0^{\circ} \\
\end{array}$ & $\begin{array}{l}65^{\circ} \\
\mathrm{S} 1^{\circ} \\
\end{array}$ & $\begin{array}{l}30^{\circ} \\
{\mathrm{M} 2^{\circ}}^{\circ}\end{array}$ \\
\hline 45 & $\begin{array}{l}60^{\circ} \\
M 2^{\circ} \\
\end{array}$ & $\begin{array}{l}15^{\circ} \\
11^{\circ} \\
\end{array}$ & $\begin{array}{l}83^{\circ} \\
M 2^{\circ} \\
\end{array}$ & $\begin{array}{l}15^{\circ} \\
S 2^{\circ} \\
\end{array}$ & 64 & $\begin{array}{l}60^{\circ} \\
11^{\circ} \\
\end{array}$ & $\begin{array}{l}21^{\circ} \\
\mathrm{L} 1^{\circ}\end{array}$ & $\begin{array}{l}60^{\circ} \\
0^{\circ} \\
\end{array}$ & $\begin{array}{l}21^{\circ} \\
M 2^{\circ}\end{array}$ \\
\hline 46 & $\begin{array}{r}55^{\circ} \\
\mathrm{L} 3^{\circ} \\
\end{array}$ & $\begin{array}{l}21^{\circ} \\
\mathrm{S} 1^{\circ}\end{array}$ & $\begin{array}{l}81^{\circ} \\
\mathrm{M} 6^{\circ} \\
\end{array}$ & $\begin{array}{l}21^{\circ} \\
S 3^{\circ} \\
\end{array}$ & 65 & $\begin{array}{l}55^{\circ} \\
0^{\circ}\end{array}$ & $\begin{array}{l}12^{\circ} \\
\mathrm{L} 1^{\circ}\end{array}$ & $\begin{array}{l}55^{\circ} \\
12^{\circ}\end{array}$ & $\begin{array}{l}12^{\circ} \\
\mathrm{M} 3^{\circ} \\
\end{array}$ \\
\hline 47 & $\begin{array}{r}50^{\circ} \\
\mathrm{M}^{\circ}\end{array}$ & $\begin{array}{l}10^{\circ} \\
0^{\circ} \\
\end{array}$ & $\begin{array}{l}83^{\circ} \\
M 5^{\circ} \\
\end{array}$ & $\begin{array}{l}10^{\circ} \\
11^{\circ}\end{array}$ & 66 & $\begin{array}{l}50^{\circ} \\
11^{\circ}\end{array}$ & $\begin{array}{l}27^{\circ} \\
\mathrm{L} 6^{\circ}\end{array}$ & $\begin{array}{l}50^{\circ} \\
13^{\circ}\end{array}$ & $\begin{array}{l}27^{\circ} \\
L 4^{\circ}\end{array}$ \\
\hline 48 & $\begin{array}{l}45^{\circ} \\
\mathrm{L} 4^{\circ}\end{array}$ & $\begin{array}{l}12^{\circ} \\
14^{\circ} \\
\end{array}$ & $\begin{array}{l}57^{\circ} \\
\mathrm{L} 2^{\circ} \\
\end{array}$ & $\begin{array}{l}12^{\circ} \\
\mathrm{S} 1^{\circ}\end{array}$ & 67 & $\begin{array}{l}45^{\circ} \\
S 2^{\circ}\end{array}$ & $\begin{array}{l}21^{\circ} \\
0^{\circ}\end{array}$ & $\begin{array}{l}45^{\circ} \\
\mathrm{S} 4^{\circ}\end{array}$ & $\begin{array}{l}21^{\circ} \\
M 3^{\circ}\end{array}$ \\
\hline 49 & $\begin{array}{c}40^{\circ} \\
0^{\circ} \\
\end{array}$ & $\begin{array}{l}18^{\circ} \\
S 6^{\circ}\end{array}$ & $\begin{array}{r}79^{\circ} \\
\mathrm{M}^{\circ}\end{array}$ & $\begin{array}{l}18^{\circ} \\
111^{\circ} \\
\end{array}$ & 68 & $\begin{array}{l}40^{\circ} \\
11^{\circ} \\
\end{array}$ & $\begin{array}{r}17^{\circ} \\
M 2^{\circ}\end{array}$ & $\begin{array}{l}40^{\circ} \\
13^{\circ} \\
\end{array}$ & $\begin{array}{r}17^{\circ} \\
\mathrm{L} 2^{\circ} \\
\end{array}$ \\
\hline 50 & $\begin{array}{l}35^{\circ} \\
M 1^{\circ} \\
\end{array}$ & $\begin{array}{l}12^{\circ} \\
0^{\circ} \\
\end{array}$ & $\begin{array}{r}99^{\circ} \\
\mathrm{L} 6^{\circ} \\
\end{array}$ & $\begin{array}{l}12^{\circ} \\
11^{\circ} \\
\end{array}$ & 69 & $\begin{array}{l}35^{\circ} \\
12^{\circ} \\
\end{array}$ & $\begin{array}{l}11^{\circ} \\
M 2^{\circ}\end{array}$ & $\begin{array}{l}35^{\circ} \\
11^{\circ} \\
\end{array}$ & $\begin{array}{l}11^{\circ} \\
\left\llcorner 3^{\circ}\right. \\
\end{array}$ \\
\hline 51 & $\begin{array}{l}30^{\circ} \\
M 2^{\circ}\end{array}$ & $\begin{array}{l}11^{\circ} \\
\mathrm{S} 1^{\circ}\end{array}$ & $\begin{array}{l}117^{\circ} \\
\mathrm{L} 6^{\circ}\end{array}$ & $\begin{array}{l}11^{\circ} \\
\mathrm{S} 2^{\circ}\end{array}$ & 70 & $\begin{array}{l}30^{\circ} \\
11^{\circ}\end{array}$ & $\begin{array}{l}31^{\circ} \\
M 5^{\circ}\end{array}$ & $\begin{array}{l}30^{\circ} \\
14^{\circ}\end{array}$ & $\begin{array}{r}31^{\circ} \\
M 7^{\circ}\end{array}$ \\
\hline 52 & $\begin{array}{r}25^{\circ} \\
0^{\circ} \\
\end{array}$ & $\begin{array}{l}21^{\circ} \\
0^{\circ} \\
\end{array}$ & $\begin{array}{l}122^{\circ} \\
\mathrm{M} \mathrm{4}^{\circ}\end{array}$ & $\begin{array}{l}21^{\circ} \\
12^{\circ} \\
\end{array}$ & 71 & $\begin{array}{l}25^{\circ} \\
\mathrm{S} 5^{\circ}\end{array}$ & $\begin{array}{l}22^{\circ} \\
M 8^{\circ} \\
\end{array}$ & $\begin{array}{l}25^{\circ} \\
15^{\circ}\end{array}$ & $\begin{array}{l}22^{\circ} \\
\mathbf{L} 5^{\circ} \\
\end{array}$ \\
\hline 53 & $\begin{array}{r}20^{\circ} \\
\mathrm{M} 4^{\circ} \\
\end{array}$ & $\begin{array}{l}21^{\circ} \\
12^{\circ} \\
\end{array}$ & $\begin{array}{l}108^{\circ} \\
\mathrm{M} 3^{\circ} \\
\end{array}$ & $\begin{array}{l}21^{\circ} \\
\mathrm{S} 2^{\circ} \\
\end{array}$ & 72 & $\begin{array}{l}20^{\circ} \\
11^{\circ} \\
\end{array}$ & $\begin{array}{l}25^{\circ} \\
M 6^{\circ} \\
\end{array}$ & $\begin{array}{l}20^{\circ} \\
16^{\circ} \\
\end{array}$ & $\begin{array}{r}25^{\circ} \\
M 3^{\circ} \\
\end{array}$ \\
\hline 54 & $\begin{array}{r}15^{\circ} \\
M 2^{\circ} \\
\end{array}$ & $\begin{array}{l}10^{\circ} \\
12^{\circ} \\
\end{array}$ & $\begin{array}{l}101^{\circ} \\
\mathrm{L} 1^{\circ} \\
\end{array}$ & $\begin{array}{l}10^{\circ} \\
11^{\circ} \\
\end{array}$ & 73 & $\begin{array}{l}15^{\circ} \\
13^{\circ} \\
\end{array}$ & $\begin{array}{l}33^{\circ} \\
M 7^{\circ} \\
\end{array}$ & $\begin{array}{l}15^{\circ} \\
11^{\circ} \\
\end{array}$ & $\begin{array}{r}33^{\circ} \\
\mathrm{L} 8^{\circ} \\
\end{array}$ \\
\hline 55 & $\begin{array}{r}10^{\circ} \\
\mathrm{M} 1^{\circ} \\
\end{array}$ & $\begin{array}{l}76^{\circ} \\
11^{\circ}\end{array}$ & $\begin{array}{l}111^{\circ} \\
M 6^{\circ}\end{array}$ & $\begin{array}{l}76^{\circ} \\
15^{\circ}\end{array}$ & 74 & $\begin{array}{l}10^{\circ} \\
12^{\circ}\end{array}$ & $\begin{array}{r}18^{\circ} \\
L 6^{\circ}\end{array}$ & $\begin{array}{c}10^{\circ} \\
0^{\circ}\end{array}$ & $\begin{array}{r}18^{\circ} \\
\mathrm{L} 3^{\circ} \\
\end{array}$ \\
\hline 56 & $\begin{array}{c}5^{\circ} \\
\mathrm{M} 4^{\circ} \\
\end{array}$ & $\begin{array}{l}12^{\circ} \\
14^{\circ} \\
\end{array}$ & $\begin{array}{l}93^{\circ} \\
M 8^{\circ} \\
\end{array}$ & $\begin{array}{l}12^{\circ} \\
\mathrm{S} 2^{\circ} \\
\end{array}$ & 75 & $\begin{array}{r}5^{\circ} \\
12^{\circ} \\
\end{array}$ & $\begin{array}{l}26^{\circ} \\
\mathrm{L} 4^{\circ} \\
\end{array}$ & $\begin{array}{c}5^{\circ} \\
S 1^{\circ} \\
\end{array}$ & $\begin{array}{r}26^{\circ} \\
\mathrm{L} 5^{\circ} \\
\end{array}$ \\
\hline 57 & $\begin{array}{l}0^{\circ} \\
0^{\circ}\end{array}$ & $\begin{array}{c}8^{\circ} \\
16^{\circ}\end{array}$ & $\begin{array}{l}95^{\circ} \\
\mathrm{L} 4^{\circ}\end{array}$ & $\begin{array}{c}8^{\circ} \\
13^{\circ}\end{array}$ & 76 & $\begin{array}{l}0^{\circ} \\
0^{\circ}\end{array}$ & $\begin{array}{l}27^{\circ} \\
\mathrm{L} 5^{\circ}\end{array}$ & $\begin{array}{l}0^{\circ} \\
0^{\circ}\end{array}$ & $\begin{array}{l}27^{\circ} \\
\mathrm{L} 3^{\circ}\end{array}$ \\
\hline
\end{tabular}

L: Lateral, M: Medial, S: Superior, I: Inferior shows the direction of the deviation of each screw. CCA: Craniocaudal angulation, LMA: Lateromedial angulation, Ped: Pedicle. 
inthe section related to the usage of this app, holding the smartphone and surgical device together in the proper position during the procedure was uncomfortable. In addition to this drawback, constantly keeping the long axis of the probes and smartphone parallel to each other was not practical. When the corner of a smartphone was not in contact with any fixed part of the vertebra (insertion point), the detection capability of the app of the alterations in the craniocaudal and lateral-medial

Table IV: Measured Parameters (Mean and Standard Deviations) for all Groups and Subgroups

\begin{tabular}{lcccc}
\hline \multirow{2}{*}{ Groups $^{*}$} & \multicolumn{4}{c}{ Mean \pm SD (degree) } \\
\cline { 2 - 6 } & \multicolumn{2}{c}{ LMA } & CCA & Right Pedicle \\
\cline { 2 - 6 } Group I a (1-19) & $3.157895 \mp 1.537066$ & $3.526316 \mp 1.576509$ & $2.105263 \mp 1.410072$ & $3 \mp 1.563472$ \\
\hline Group I b (20-38) & $2.210526 \mp 1.182227$ & $2.210526 \mp 1.718492$ & $1.947368 \mp 1.17727$ & $2.052632 \mp 1.393385$ \\
\hline Group II a (39-57) & $3.578947 \mp 2.292882$ & $1.894737 \mp 1.04853$ & $2 \mp 1.452966$ & $2.157895 \mp 1.803181$ \\
\hline Group II b (58-76) & $3.105263 \mp 1.997074$ & $1.894737 \mp 1.822536$ & $3.157895 \mp 2.609026$ & $1.473684 \mp 1.218762$ \\
\hline Group I Total (1-38) & $2.684211 \mp 1.435181$ & $2.868421 \mp 1.757933$ & $2.026316 \mp 1.28372$ & $2.526316 \mp 1.53758$ \\
\hline Group II Total (39-76) & $3.342105 \mp 2.134356$ & $1.894737 \mp 1.466555$ & $2.578947 \mp 2.163975$ & $1.815789 \mp 1.557116$ \\
\hline CCA: Craniocau
\end{tabular}

CCA: Craniocaudal angulation, LMA: Lateromedial angulation.

*According to $t$-test results, there is no statistically significant difference in right pedicle LMA scores between group $1(M=2.026, S D=0.208)$ and group $2(M=2.579, S D=0.351), p=0.180>0.05$. Similarly, there is no statistically significant difference in left pedicle $L M A$ scores between group $1(M=2.684, S D=.233)$ and group $2(M=3.342, S D=0.346), p=0.120>0.05$. On the other hand, there is a statistically significant difference between the two groups in the right pedicle $(C C A)$, group $1(M=2.526, S D=0.249)$ and group $2(M=1.816, S D=0.253), p=0.049<0.05$. There is also a significant difference in the left pedicle (CCA), group $1(M=2.868, S D=0.285)$ and group $2(M=1.895, S D=0.238), p=0.010<0.05$. There are no significant differences between the groups $1 \mathrm{a}$ and $1 \mathrm{~b}$ in the Right Pedicle (LMA) $(p=0.1799)$ and in the right pedicle (CCA) ( $p=0.056)$; however on other measures, groups $1 \mathrm{a}$ and $1 \mathrm{~b}$ score differently. For left pedicle $L M A$, the difference between the groups is statistically significant at $p=0.040<0.05$. Also, there is a statistically significant difference between groups $1 \mathrm{a}$ and $1 \mathrm{~b}$ in the left pedicle CCA, $p=0.019<0.05$. Among groups $2 a$ and $2 b$, there is a statistically significant difference only for the right pedicle $L M A, p=0.10<0.05$. Statistically significant differences for other measures such as the left pedicle LMA, right pedicle CCA, or left pedicle CCA were not observed.

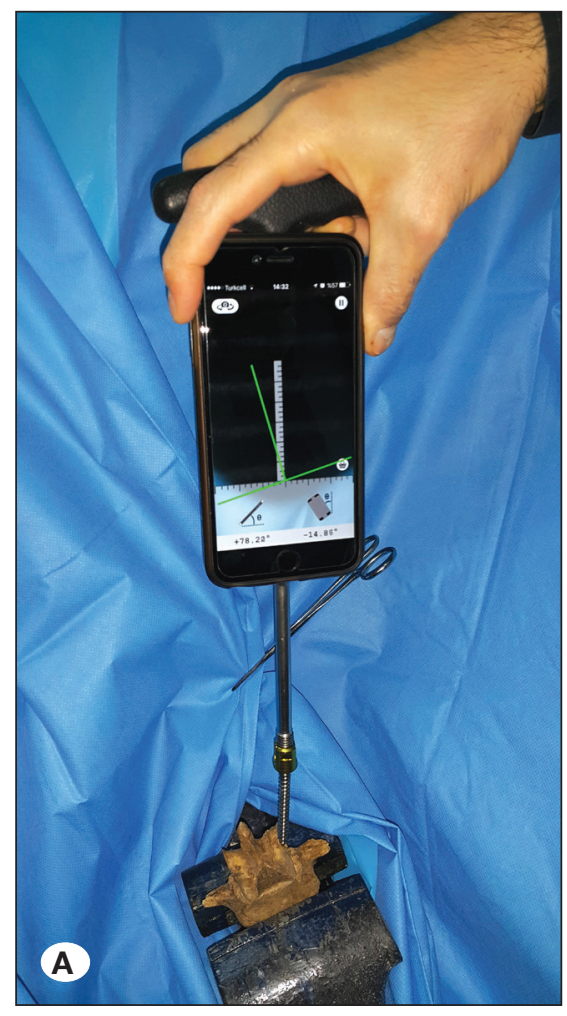

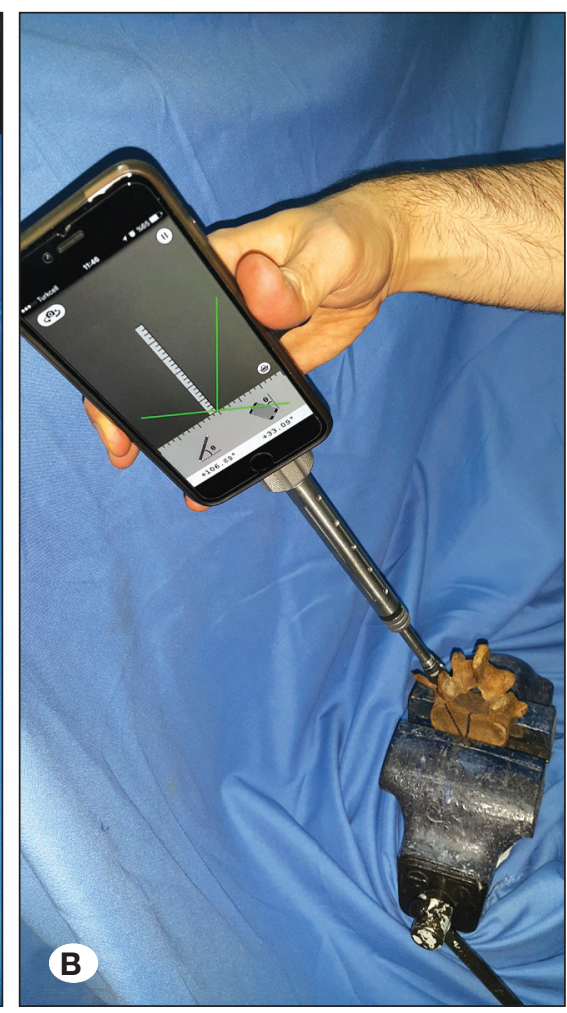

Figure 8: Different position of smartphone contrary to our defined standart position in lateromedial direction (A), and craniocaudal direction (B). 
directions was impaired. When the smartphone was kept away from insertion point, just near the head of probe, only one angulation was sensed (Figure 8A, B). In these situations, it is better to move the probe according to the lower degree than bring the probe to the desired final position according to the other angle. However, if the angulation of lower degree is above 35-40 degrees, it may not be possible to direct the probe to the desired trajectory angles. Specific regions in the probe compatible with the smartphones that can fix them throughout the process can be seen as a solution. Therefore, a special probe design for smartphones, which can be attached, is needed. The best results are obtained by holding the corner of the smartphone just over the defined enter point, which was not practical.

The program was designed to measure the angulation of the smartphone's either screen and back according to the ground or lateral borders using an imaginary line perpendicular to the ground. In our study, we realized that this app could measure and sense the angulations correctly in both movement directions at the same time up to 60-65 degrees. After this limit, it is more accurate to position the smartphone to the desired angles step by step. Firstly, lateral border of smartphone should be moved when the smartphone's whole body exists in the vertical plane and secondly the smartphone's back is being repositioned taking care not to change the first determined angle. As another method, it is much more practical to determine the lower angle first. Therefore, attaching the smartphone to any holder and using it this way will help the surgeon measure only one angulation exactly. Although this type of use is quite practical, it is very inefficient due to the fact that it merely displays one direction.

Our one other acquisition from this "anatomical dry vertebra model", in addition to finding an opportunity to test this application in differently sized and regional vertebrae, was to examine its accuracy in different trajectory angles for the sagittal and horizontal planes due to the fact that it allows immobilized vertebrae in different configurations. We could have found an opportunity to use this app in extreme angles and also force the limits and capacity of this app. In a cadaver model, only small angles can be tried out of our vice-vertebra model.

As far as we know, there is no smartphone app that may be adapted to spinal practice. Also, there are apps for preoperative management of spinal deformity; no app has been allowed to be used as a surgical device.

In this study, the reason for choosing a single vertebra instead of a cadaver was to test this app for various angles. In deformed spines, the limits of vertebral alignment are strained and the surgeon should insert the screws in extreme angles. There are also various techniques for free hand use and various anatomical studies have been done focusing on the proper trajectory angle. In these cases, the defined trajectory angles and directions may be insufficient and misleading.

During the use of screw handles with a smartphone for the purpose of inserting the screws in the proper positions according to the designated measurement for each vertebra an unfavorable aspect of this work is that one corner of the phone should contact the ground for measuring the two angulations at the same time. Higher locations of the smartphone according to the ground will result in more false results.

Additionally it also can be designed if screw is attached to the transmitter and positioned in the direction of angle gauge, but results when the corner of a smartphone was not in contact with any fixed part of the vertebra would not be better from previously gauge added.

Surgical neuroanatomical knowledge is very important but spinal surgeons have to use technology to be $100 \%$ accurate in order to obtain proper screw insertion. Practical and safe methods and devices need to be developed. It is worth to remember the reality that even one screw malposition among ten correctly placed ones may cause a severe permanent deficit or chronic pain. Smaller and integrated systems such as the selected mobile app seem to be a necessity to perform spinal instrumentations.

Eventually, the related app seems not to be clinically practical but it may give an opinion and be the guide for future studies and innovations regarding spinal instrumentations and other surgical interventions. Because intraoperative optical measurements during surgery cannot be accurate due to many reasons, our aim was not to develop optical measurement technology. The researchers only examined the accuracy and feasibility of the smartphone and smartphone application in a model by standard accepted morphometical and anatomical methods in this study. Also, both in vitro and in vivo larger studies are needed to evaluate the accuracy of such applications. Nevertheless, our study is important as the first in its field in terms of testing the screws in higher angulations using a novel vice model.

Movement of the smartphone around its long-axis or base circumferentially is not sensed by the application when its short border or base respectively totally stays on the ground. Eventually, the related app seems not to be clinically practical but it may give an opinion and be the guide for future studies and innovations regarding spinal instrumentations and other surgical interventions. Also both in vitro and in vivo larger studies are needed to evaluate the accuracy of such applications. Integration of this app to spinal instrumentation procedures with hand held computers attachable to surgical devices might increase the accuracy of previous techniques and current high tech products.

\section{- CONCLUSION}

Our study focusing on examining the accuracy and feasibility of a mobile app based on a vertebra-vice model to adapt pedicle screw placement procedures to daily surgical practice distinctly shows that the idea of pedicle screw placement under the assistance of the angle-meter smartphone application may be a futuristic line of vision for modern spinal surgeries.

Although there are disadvantages in terms of its applicability to real-life spinal surgeries due to the size of smartphones, 
development of much smaller accessories in the future that can be connected to a smartphone and fit in the surgical field which allow surgeons to work more comfortably and increase its feasibility.

The anatomical dry vertebra model is good for simulation pedicle screw placements and to test angle measurements. With suitable attachments and by preoperative measurements angle-meter app can be a useful tool to navigate trajectory and for accurate orientation during screw insertion. New designs for intraoperative attachments showing plane and handling attachments showing inclination will improve accuracy and their use during surgery.

\section{REFERENCES}

1. Dogan I, Eroglu U, Ozgural O, Al-Beyati ESM, Kilinc MC, Comert A, Bozkurt M: Visualization of superficial cerebral lesions using a smartphone application. Turk Neurosurg 28(3):349-355, 2018

2. Eftekhar B: A smartphone app to assist scalp localization of superficial supratentorial lesions-technical note. World Neurosurg 85:359-363, 2016

3. Eftekhar B: App-assisted external ventricular drain insertion. J Neurosurg 125:754-758, 2016

4. Kahn JG, Yang JS, Kahn JS: 'Mobile' health needs and opportunities in developing countries. Health Aff (Millwood) 29:252-258, 2010

5. Kim YJ, Lenke LG: Thoracic pedicle screw placement: Freehand technique. Neurol India 53:512-519, 2005

6. Kim YJ, Lenke LG, Bridwell KH, Cho YS, Riew KD: Free hand pedicle screw placement in the thoracic spine: Is it safe? Spine 29:333-342, 2004

7. Kotani $\mathrm{Y}$, Abumi $\mathrm{K}$, Ito $\mathrm{M}$, Minami A: Improved accuracy of computer-assisted cervical pedicle screw insertion. J Neurosurg 99:257-263, 2003

8. Laine T, Schlenzka D, Makitalo K, Tallroth K, Nolte LP, Visarius $\mathrm{H}$ : Improved accuracy of pedicle screw insertion with computer assisted surgery. A prospective clinical trial of 30 patients. Spine 22:1254-1258, 1997
9. Mobasheri $M H$, Johnston $M$, Syed UM, King D, Darzi $A$ : The uses of smartphones and tablet devices in surgery: $A$ systematic review of the literature. Surgery 158:1352-1371, 2015

10. Panjabi MM, Takata K, Goel V, Federico D, Oxland T, Duranceau J, Krag M: Thoracic human vertebrae. Quantitative three-dimensional anatomy. Spine 16:888-901, 1991

11. Payne KB, Wharrad H, Watts K: Smartphone and medical related App use among medical students and junior doctors in the United Kingdom (UK): A regional survey. BMC Med Inform Decis Mak 12:121, 2012

12. Rajasekaran S, Vidyadhara S, Ramesh P, Shetty AP: Randomized clinical study to compare the accuracy of navigated and non-navigated thoracic pedicle screws in deformity correction surgeries. Spine 32:E56-E64, 2007

13. Roy-Camille R, Saillant G, Mazel C: Internal fixation of the lumbar spine with pedicle screw plating. Clin Orthop Relat Res 203:7-17, 1986

14. Tian NF, Huang QS, Zhou P, Zhou Y, Wu RK, Lou Y, Xu HZ: Pedicle screw insertion accuracy with different assisted methods: A systematic review and meta-analysis of comparative studies. Eur Spine J 20:846-859, 2011

15. Vaccaro AR, Rizzolo SJ, Allardyce TJ, Ramsey M, Salvo J, Balderston RA, Cotler JM: Placement of pedicle screws in the thoracic spine. Part I: Morphometric analysis of the thoracic vertebrae. J Bone Joint Surg (Am) 77:1193-1199, 1995

16. Vaccaro AR, Rizzolo SJ, Balderston RA, Allardyce TJ, Garfin SR, Dolinskas C, An HS: Placement of pedicle screws in the thoracic spine. Part II: An anatomical and radiographic assessment. J Bone Joint Surg (Am) 77:1200-1206, 1995

17. Wiesner L, Kothe R, Ruther W: Anatomic evaluation of two different techniques for the percutaneous insertion of pedicle screws in the lumbar spine. Spine 24:1599-1603, 1999

18. Zausinger S, Scheder B, Uhl E, Heigl T, Morhard D, Tonn JC: Intraoperative computed tomography with integrated navigation system in spinal stabilizations. Spine 34:29192926, 2009 